\title{
STUDENTS SATISFACTION ON BILINGUAL PROGRAM IN MAKASSAR
}

\author{
Andi Hamzah Fansury ${ }^{1,}$ Rampeng ${ }^{2}$ \\ ${ }^{1,2}$ Faculty of Teacher Training and Education, Bosowa University, \\ Makassar, Indonesia
}

\begin{abstract}
The objectives of the research were (1) to describe the students satisfaction on bilingual program at secondary school in Makassar and (2) to find out the students' interest and motivation in learning English through Bilingual Program. The researcher applied mixed method namely triangulation mixed method design (QUAN-QUAL). The population of this research was the students of SMPN 12 Makassar in academic year 2015/2016. This research used purposive sampling. The sample of this research consisted of 40 students; 20 students from seventh grade and 20 students eight grade. In this research also, the researcher took 40 parents and 10 teachers as a sample. The research data were collected by questionnaire which was analyzed by descriptive statistic through SPSS version 16 for windows program. The result of data analysis shown that bilingual program improve English students skills, bilingual program makes the students mastery in English and learn it in their subjects matter (Mathematics, Science, and English). Bilingual also makes the students have better skills in learning English and, bilingual program has helped the students to develop as a person (students' personality). The implementation of bilingual program at secondary school make the students are interested and motivated in learning English. From this fact, it points out the way of school and the governments to keep this program and make a policy to make this program keep going
\end{abstract}

Keywords: Students Satisfaction, Bilingual Program

\section{INTRODUCTION}

English is one of the international languages that are used worldwide. In Indonesia, English is a subject to learn from elementary school to university levels. Although the students had learned English from a very early stage in elementary school levels to university level for more than six years, students' proficiency in using English is still considered low in level. Many students are not able to speak in English.

The condition of low level of students' proficiency in using English leads the government to concern more on how to solve the problem. One of the causes is that English is taught as a foreign language and then the government takes an 
initiative to create a program to make the students use English. One of the efforts made by government is by developing a bilingual program.

Bilingual program refers to the use of two (or more) languages of instruction at some point in a student's school. The languages are used to teach subject matter content rather than just the language itself. There are three main concepts used in bilingual education that reveal important distinctions in practice: language immersion, monolingual, and bilingual.

Bilingual program in Makassar, use English as the instructional language for certain subjects such as Mathematics and Science. Since Indonesian language is the mother tongue, and English is the foreign language, the school will face a difficulty to use English as the instructional language in teaching and learning activities. Teaching means guiding and facilitating learning, enabling the learner to learn, and setting the conditions for learning (Brown, 1994: 7), it means in teaching, there is communication between teacher and students. Communication means the exchange and negotiation of information between at least two individuals through the use of verbal and non-verbal symbols, oral and written models, and production and comprehension processes (Richards \& Schmidt, 1983: 4).

Bilingual program is a new program, how it is run and implemented is still in question until now. The use of English in teaching and learning activities, especially in English is better than before or not.

\section{METHODOLOGY}

In this research, the researcher applied Mixed method research design. Types of this research are QUAN-QUAL model. The QUAN-QUAL model, also known as the triangulation mixed method design. Quantitative and qualitative data are equally weighted and collected currently throughout the same study. The population of this research was the students of SMPN 12 Makassar in academic year 2012/2013. This research used purposive sampling. The sample of this research consisted of 40 students; 20 students from seventh grade and 20 students eight grade. In this research also, the researcher took 40 parents and 10 teachers as a sample. The research data were collected by questionnaire which was analyzed by descriptive statistic through SPSS version 16 for windows program.

\section{FINDINGS}

\section{Students Satisfaction on Bilingual Program in Makassar}

This section deals with the presentation and the elaboration of data from questionnaires about the student's satisfaction on bilingual program in improving English students skills. The scoring of the questionnaires was analyzed statistically based on the application of Likert Scale. The result shows the student's satisfaction on bilingual program. This is indicated by the percentage of the students', parents, and teacher questionnaire shown in the following: 


\section{a. Students' Progress with Particular Language Skills}

Table 1. The Percentage of Students' Progress with Particular Language Skills

\begin{tabular}{|l|l|l|l|l|}
\hline No. & Classification & Range & Frequency & Percentage \\
\hline 1. & Very Good & $85-100$ & 7 & $17,5 \%$ \\
\hline 2. & Good & $69-84$ & 26 & $65 \%$ \\
\hline 3. & Neutral & $51-68$ & 7 & $17,5 \%$ \\
\hline 4. & Not Good & $36-50$ & 0 & 00.00 \\
\hline 5. & Not at All Good & $20-35$ & 0 & 00.00 \\
\hline Total & & 40 & 100 \\
\hline
\end{tabular}

Based on the classification above, it indicated that the overall responses were only in very good, good and neutral classification. From 40 students, 7 $(17.5 \%)$ of them reached the high classification, very good. The rest 26 students $(65.00 \%)$ were categorized as good classification. And, $7(17.5 \%)$ of them reached the high classification, neutral. From all classifications, none of the students were categorized as not good and Not at All good. From the data, it was found that all of the students said that bilingual education has helped them make good progress with particular language skills.

Table 2. The Mean Score of Students' Progress with Particular Language Skills

\begin{tabular}{|l|l|l|}
\hline $\begin{array}{l}\text { Total } \\
\text { Respondent }\end{array}$ & Total of Students' Score & $\begin{array}{l}\text { Mea } \\
\mathrm{n}\end{array}$ \\
\hline 40 & 3220 & 80.5 \\
\hline
\end{tabular}

In relation to the mean score above, the students reached 80.5 It can be concluded that bilingual education has helped the students of SMPN 12 Makassar to make good progress with particular language skills.

b. Bilingual Program in Develop Students Personality

Table 3. The Percentage of Bilingual Program in Develop Students Personality

\begin{tabular}{|l|l|l|l|l|}
\hline No. & Classification & Range & $\begin{array}{l}\text { Frequen } \\
\text { cy }\end{array}$ & $\begin{array}{l}\text { Percentag } \\
\text { e }\end{array}$ \\
\hline 1. & Yes, Definitely & $85-100$ & 8 & $20 \%$ \\
\hline 2. & Yes & $69-84$ & 28 & $70 \%$ \\
\hline 3. & Neutral & $51-68$ & 4 & $10 \%$ \\
\hline 4. & No & $36-50$ & 0 & 00.00 \\
\hline 5. & Definitely Not & $20-35$ & 0 & 00.00 \\
\hline Total & 40 & 100 \\
\hline
\end{tabular}


Based on the classification above, it indicated that the overall responses were only in yes, definitely, yes, and neutral classification. From 40 students, 8 $(10 \%)$ of them reached the high classification, yes, definitely. The rest 28 students $(70 \%)$ were categorized as yes classification. And, $4(10 \%)$ of them reached the high classification, neutral. From all classifications, none of the students were categorized as No and Definitely Not. From the data, it was found that all of the students said that bilingual education has helped the students to develop as a person (students personality) and to increase their choices in life.

Table 4. The Mean Score of Bilingual Program in Develop Students Personality

\begin{tabular}{|c|c|c|}
\hline $\begin{array}{l}\text { Total } \\
\text { Respondent }\end{array}$ & $\begin{array}{l}\text { Total of Students' } \\
\text { Score }\end{array}$ & Mean \\
\hline 40 & 3264 & 81.6 \\
\hline
\end{tabular}

In relation to the mean score above, the students reached 81.6. It can be concluded that bilingual education has helped the students to develop as a person (students personality) and to increase their choices in life.

c. Bilingual Program Helped Students to Speak English

Table 5. The Percentage of Bilingual Program Helped Students to Speak English

\begin{tabular}{|l|l|l|l|l|}
\hline No. & Classification & Range & Frequency & $\begin{array}{l}\text { Percentag } \\
\text { e }\end{array}$ \\
\hline 1. & Yes, Definitely & $85-100$ & 10 & $25 \%$ \\
\hline 2. & Yes & $69-84$ & 25 & $62.5 \%$ \\
\hline 3. & Neutral & $51-68$ & 5 & $12.5 \%$ \\
\hline 4. & No & $36-50$ & 0 & 00.00 \\
\hline 5. & Definitely Not & $20-35$ & 0 & 00.00 \\
\hline \multicolumn{2}{|l|}{ Total } & 40 & 100 \\
\hline
\end{tabular}

Based on the classification above, it indicated that the overall responses were only in yes, definitely, yes, and neutral classification. From 40 parents, 10 (25\%) of them reached the high classification, Yes, Definitely. The rest 25 parents $(62.5 \%)$ were categorized as yes classification. And, $5(12.5 \%)$ of them reached the high classification, neutral. From all classifications, none of the students were categorized as No and Definitely Not. From the data, it was found that all of the students said that bilingual education has helped Students to Speak English. 
Table 6. The Mean Score of Bilingual Program Helped Students to Speak English

\begin{tabular}{|c|c|c|}
\hline $\begin{array}{l}\text { Total } \\
\text { Respondent }\end{array}$ & $\begin{array}{l}\text { Total of Students' } \\
\text { Score }\end{array}$ & Mean \\
\hline 40 & 3319 & 82.98 \\
\hline
\end{tabular}

In relation to the mean score above, the parents reached 82.98. It can be concluded that bilingual program has helped the students to make good progress in English.

d. Students' Interest in Bilingual Program

Table 7. The Percentage of Students' Interest in Bilingual Program

\begin{tabular}{|l|l|l|l|l|}
\hline No. & Classification & Range & Frequency & $\begin{array}{l}\text { Percentag } \\
\text { e }\end{array}$ \\
\hline 1. & Very Interesting & $85-100$ & 5 & $12,5 \%$ \\
\hline 2. & Interesting & $69-84$ & 30 & $75 \%$ \\
\hline 3. & Neutral & $51-68$ & 5 & $12,5 \%$ \\
\hline 4. & Not Interesting all & $36-50$ & 0 & 00.00 \\
\hline 5. & $\begin{array}{l}\text { Not at Al } \\
\text { Interesting }\end{array}$ & 0 & 00.00 \\
\hline Total & 40 & 100 \\
\hline
\end{tabular}

Based on the classification above, it indicated that the overall responses were only in interesting, very interesting and neutral classification. From 40 students, $5(12.5 \%)$ of them reached the high classification, very interesting. The rest 30 students $(75.00 \%)$ were categorized as interesting classification. And, 5 $(12.5 \%)$ of them reached the high classification, neutral. From all classifications, none of the students were categorized as not interesting and Not at All interesting. From the data, it was found that all of the students had interest with bilingual program.

Table 8. The Mean Score of Students' Interest in Bilingual Program

\begin{tabular}{|l|l|l|}
\hline $\begin{array}{l}\text { Total } \\
\text { Respondent }\end{array}$ & $\begin{array}{l}\text { Total of Students' } \\
\text { Score }\end{array}$ & Mean \\
\hline 40 & 2820 & 70.5 \\
\hline
\end{tabular}

In relation to the mean score above, the students reached 70.5 , it can be concluded that the students of SMPN 12 Makassar had interest in bilingual program. 
Table 9. The Percentage of Students' Motivation in Bilingual Program

\begin{tabular}{|l|l|l|l|l|}
\hline No. & Classification & Range & Frequency & $\begin{array}{l}\text { Percentag } \\
\text { e }\end{array}$ \\
\hline 1. & Very Motivating & $85-100$ & 15 & $37,5 \%$ \\
\hline 2. & Motivating & $69-84$ & 20 & $50 \%$ \\
\hline 3. & Neutral & $51-68$ & 5 & $12,5 \%$ \\
\hline 4. & Not Motivating all at Al & $36-50$ & 0 & 00.00 \\
\hline 5. & $\begin{array}{l}\text { Not } \\
\text { Motivating }\end{array}$ & 0 & 00.00 \\
\hline Total & & 40 & 100 \\
\hline
\end{tabular}

Based on the classification above, it indicated that the overall responses were only in Motivating, very Motivating and neutral classification. From 40 students, $15(37,5 \%)$ of them reached the high classification, very motivating. The rest 30 students $(50.00 \%)$ were categorized as motivating classification. And, $5(12.5 \%)$ of them reached the high classification, neutral. From all classifications, none of the students were categorized as not motivating and Not at All Motivating. From the data, it was found that all of the students had interest with bilingual program.

Table 10. The Mean Score of Students' Interest in Bilingual Program

\begin{tabular}{|c|c|c|}
\hline Total Respondent & $\begin{array}{l}\text { Total of Students' } \\
\text { Score }\end{array}$ & Mean \\
\hline 40 & 3125 & 78.1 \\
\hline
\end{tabular}

In relation to the mean score above, the students reached 70.5 , it can be concluded that the students of SMPN 12 Makassar had interest in bilingual program.

\section{DISCUSSION}

The bilingual program is using L1 (Indonesian language) and L2 (foreign language "English") to learn content of subject matter, in this case Mathematics and Science. In this research context, the teaching model which is carried out in the bilingual program is bilingual transitional education. When the teachers taught the materials, they used partial English rather than full English. It is in line with Krashen (1997), who states that bilingual transitional education shows the use of language partially. The longer time teachers use English, the greater amount of the vocabulary the students get. Bilingual teaching in some subjects matter, 
Mathematics and Science, has purpose to prepare the students to have International standard and global competitiveness ability.

In bilingual education, the students have better skills in learning English than other schools which only use one language as the medium of instruction. During teaching learning activities, the teachers always gave the students material, either tasks or note, in English. They also tried to make communication with their students in English. It showed that they were making every effort so that in the future the students are able to communicate in English fluently and help them to cope with global competition and cooperation.

Parents play an important role in the education of their children. Their involvement and encouragement can help a child excel. Alberta Education encourages parents to an active role in education of their children and provides resources to support their involvement.

Teachers in bilingual education are required to be creative and open minded. It means that the teachers should avoid delivering the materials in conventional techniques. A teacher should apply the most efficient methods, strategies, procedures, and principles so that learners will develop to their maximum capabilities In School, where the researcher did the research, the teachers delivered the materials in English, so they attempted to make the materials interesting. Before the teacher gave the explanation about the topic they taught, they asked the students to make a simple experiment or a simple practice about the topic. It was done to make the students understand the concept of the topic that they had just learned. By doing this, the teacher expected the students to become active and enthusiastic in the teaching learning activities.

Based on the result of the questionnaire, the interest of the students was dominantly classified as interesting. There was none of them classified as not interesting and not at all interesting. From this fact, it points out the way of school to keep this program. Because in bilingual education, the students have better skills in learning English than other schools which only use one language as the medium of instruction. It is not easy to carry out bilingual program, especially in using two languages as the medium of instruction. It must be seen from any side (school, teacher, students, and parents, even the government) to make it better. It is like what Astika (2009 in Vina 2010:81) said that when the government wants to make the better education, especially in carrying out bilingual program, the government does not ignore any side that has relation each other in doing the program. After knowing the best ways in carrying out bilingual program, it is hoped that it will be an achievement of Indonesian government in educational field.

\section{CONCLUSION}

Based on the research findings and discussion it can be concludes that Bilingual program improve English students skills, bilingual program makes the students mastery in English and learn it in their subjects matter (Mathematics, 
Science, and English). Bilingual also makes the students have better skills in learning English and, bilingual program has helped the students to develop as a person (students' personality). The implementation of bilingual program at secondary school make the students are interested and motivated in learning English. From this fact, it points out the way of school and the governments to keep this program and make a policy to make this program keep going

\section{REFERENCE}

Ardian, Vina. (2010). The Implementation of Bilingualism in The Teaching Learning Activities at International Standardized School. Unpublished Thesis. Surakarta : Sebelas Maret University

Arikunto, S. (2006). Prosedur Penelitian. Suatu Pendekatan Praktik. Jakarta: Rineka Cipta

Bax. (2010). Researching English Bilingual Education in Thailand, Indonesia and South Korea. Crella : University of Bedfordshire

Bialystok, E. (2001). Bilingualism in development : Language, Literacy, and Cognition. New York : Cambridge University Press.

Celce - Murcia, M. (2001). Teaching English as A Second or Foreign Languange. Boston : Heinle \& Heinle.

Direktorat Pembinaan Sekolah Menengah Pertama. (2008). Panduan Pelaksanaan Pembinaan Rintisan Sekolah Menengah Pertama Bertaraf Internasional. Jakarta : Departemen Pendidikan Nasional.

Firman and tolla. (2008). The Future of Schooling in Indonesia. CICE Hiroshima University, Journal of International Cooperation in Education, Vol.11 No.1 pp.71-84

Gay, R.L., E. Mills, Peter. (2006). Educational Research: Competencies for Analysis and Application. New Jersey: Merrill Prentice Hall.

Haryanto. (2008). Metode Penelitian Kualitatif: Teori Dasar. Makassar: Badan Penerbit Universitas Negeri Makassar.

Hidayat, Marzul and Ella Masita. (2006). The Bilingual Education at SMPN 1 Jambi. Teachers' Problems and their Initiative Solutions. TEFLIN Journal Articles 2006 Disc Collection Universitas Negeri Malang. Publisher: Malang

Hong, J. (2010). An overview of bilingual education. Summary of Successful bilingual and immersion education models/programs, by Pacific Policy Research Center. Honolulu: Kamehameha Schools- Research \& Evaluation. 